Key words: Asian region, trade cooperation, index of trade complementarity, export specialization index, export, import, geographic structure, commodity structure.

УДК 330.341.1(5)

O. Bezzubchenko

T. Skliarova

\title{
MODERN TRENDS IN THE ASIA -PACIFIC AREA COUNTRIES INNOVATIVE ACTIVITY
}

The purpose of the research is to analyze the innovation activities of the Asia-Pacific region, mainly the leaders of the ASEAN Integration Association.

The research applied case study analysis from Asia-Pacific area high-tech sector. The research is of a qualitative nature and based on secondary data.

During the research, the basic methods of scientific knowledge were used: analysis, synthesis, modeling, description, measurement, etc. The method of correlation-regression analysis is used to determine the impact of high-tech export and $R \& D$ expenses on countries' GDP.

Keywords: ASEAN, innovation activities, high-tech industries, R\&D

DOI 10.34079/2226-2822-2019-9-17-87-96

Integration of ASEAN countries will promote the development and implementation of existing science, technology and innovation potential. The share of high-tech exports in the export structure of the integration association countries, in comparison with other developed countries, is rather weakly integrated into the global innovation space (Table 1).

Table 1

The level of integration of the national high-tech industries into the world economy in 2017, USD.

\begin{tabular}{|l|c|l|c|}
\hline \multicolumn{1}{|c|}{ Countries } & $\begin{array}{l}\text { High-tech export } \\
\text { (thousand USD) }\end{array}$ & \multicolumn{1}{|c|}{ Countries } & $\begin{array}{c}\text { High-tech export } \\
\text { (\% of industrial } \\
\text { goods export) }\end{array}$ \\
\hline China & 504380837924 & Philippines & $57,7 \%$ \\
\hline Singapore & 136160944489 & Singapore & $49,2 \%$ \\
\hline Japan & 83661306984 & Laos & $34 \%$ \\
\hline South Korea & 72699710197 & Brunei & $29,9 \%$ \\
\hline Malaysia & 41172608986 & Malaysia & $28,1 \%$ \\
\hline Philippines & 32144258015 & Vietnam & $26,9 \%$ \\
\hline Indonesia & 3956863169 & China & $22 \%$ \\
\hline Myanmar & 285944561 & Thailand & $14,2 \%$ \\
\hline Brunei & 159575567 & South Korea & $13,8 \%$ \\
\hline Thailand & 34720646,34 & Japan & \\
\hline
\end{tabular}


ISSN 2518-1394 (Online), ISSN 2226-2822 (Print) ВІСНИК МАРІУПОЛЬСЬКОГО ДЕРЖАВНОГО УНІВЕРСИТЕТУ СЕРІЯ: ЕКОНОМІКА, 2019, ВИП 17

\begin{tabular}{|l|c|l|c|}
\hline \hline Laos & 274940,69 & Myanmar & $6,1 \%$ \\
\hline Cambodia & 39805,15 & Indonesia & $5,4 \%$ \\
\hline Vietnam & 38736 & Cambodia & $0,43 \%$ \\
\hline
\end{tabular}

It is worth noting that there is a close connection between the competitiveness level of the country and the level of its innovative development, which follows from the conditions for the developed countries to achieve an effective and competitive economy.

In fact, global innovation positions are occupied by the same countries that lead rating of international competitiveness of national economies (Table 1), which again indicates the interconnection of the country's competitiveness and its level of innovation and technological development. The positions of the countries in the ratings may be slightly different but the overall trend is completely preserved.

Table 2

The ranking of countries in the global innovation index (2018)

\begin{tabular}{|c|c|c|c|c|c|}
\hline Country & Place & Rating & Country & Place & Rating \\
\hline Switzerland & 1 & 68,4 & South Korea & $\mathbf{1 2}$ & $\mathbf{5 6 , 6 3}$ \\
\hline Netherlands & 2 & 63,3 & Japan & $\mathbf{1 3}$ & $\mathbf{5 4 , 9 5}$ \\
\hline Sweden & 3 & 63,08 & Hong Kong (China) & $\mathbf{1 4}$ & $\mathbf{5 4 , 7 2}$ \\
\hline Great Britain & 4 & 60,13 & China & $\mathbf{1 7}$ & $\mathbf{5 3 , 0 6}$ \\
\hline Singapore & $\mathbf{5}$ & $\mathbf{5 9 , 8 3}$ & Malaysia & $\mathbf{3 5}$ & $\mathbf{4 3 , 1 6}$ \\
\hline The USA & 6 & 59,81 & Thailand & $\mathbf{4 4}$ & $\mathbf{3 8}$ \\
\hline Finland & $\mathbf{7}$ & 59,63 & Vietnam & $\mathbf{4 5}$ & $\mathbf{3 7 , 9 4}$ \\
\hline Denmark & 8 & 58,39 & Brunei & $\mathbf{6 7}$ & $\mathbf{3 2 , 8 4}$ \\
\hline Germany & 9 & 58,03 & Philippines & $\mathbf{7 3}$ & $\mathbf{3 1 , 5 6}$ \\
\hline Ireland & 10 & 57,19 & Indonesia & $\mathbf{8 5}$ & $\mathbf{2 9 , 8}$ \\
\hline Israel & 11 & 56,79 & Cambodia & $\mathbf{9 8}$ & $\mathbf{2 6 , 6 9}$ \\
\hline
\end{tabular}

There is significant inequality in the innovative and technological development of the ten ASEAN members. According to Global Innovation Index 2018 (Cornell University, INSEAD), Singapore is 5th in the ranking, South Korea - 12, Japan - 13, China - 17, Malaysia - 35th place. Only these countries are in the top 50 of this rating. From Appendix B it can be seen that in general countries of the Asia-Pacific region are close in the level of innovation development. Exceptions are countries such as Singapore (59.83\%), South Korea (56.63\%), Japan (54.95\%), and China (53.06\%). [2]

One of the most important indicators of innovation activity is the gross internal amount of research and development expenses. It includes the amount of business expenses for carrying out research activities, the financing amount of research activities by the state and foreign financing (Figure 1).

R\&D expenses in ASEAN countries remains low. Figure 1 shows a comparison of R\&D expenses in ASEAN countries. The Singapore index $(2.2 \%)$ is lower than in South Korea $(4.23 \%)$ and Japan $(3.28 \%)$, but higher than in China $(2.07 \%)$ and Malaysia $(1.3 \%)$ which indicates that Singapore is at the level of the main developed countries and stands out from other ASEAN member countries. 


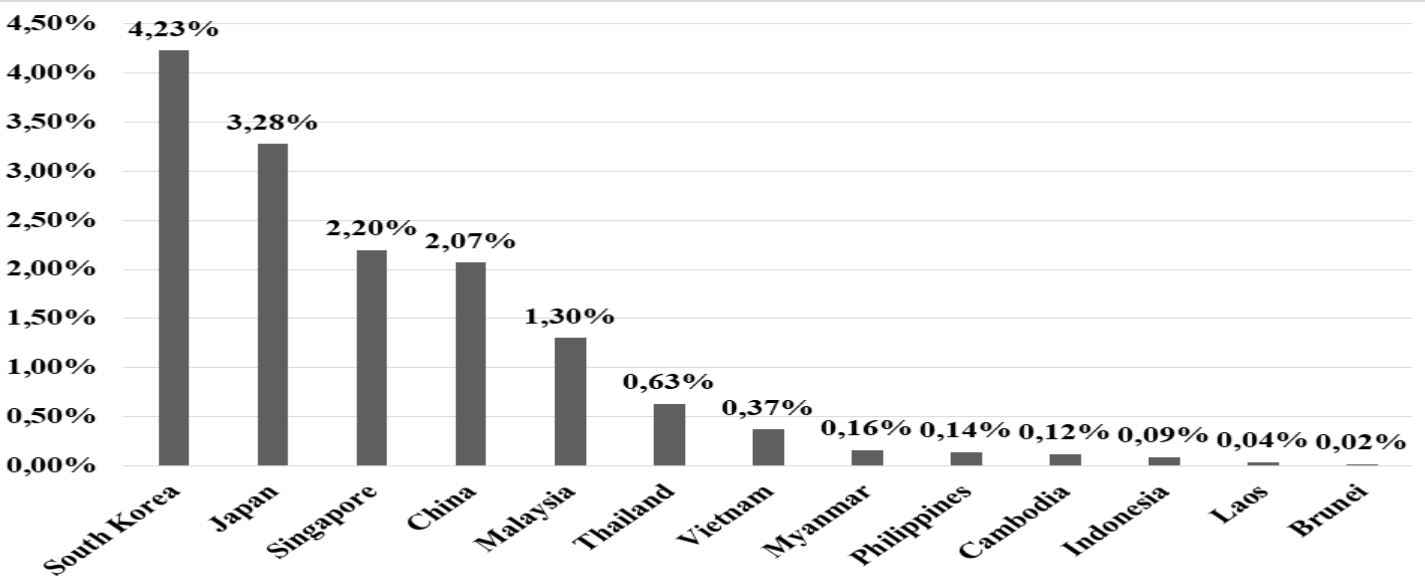

Fig.1 - R\&D expenses in the GDP structure 2016, \%

Studying the global indicators of scientific publications (Table 3), it can be said that the innovation activity indicators in this region are generally low. The region produces $22.3 \%$ of the total number of scientific publications in the world (ASEAN only $2.35 \%$ ). Patent statistics are the main indicator of innovation potential and one of the key indicators of technological development of countries and regions (Table 4). The share of ASEAN is about $30 \%$ of the world's total patents. According to statistics, the countries that have the largest patents for inventions are China, the United States and Japan. It is from there, the newest technologies and goods are exported the most to all other countries. For countries like Cambodia, Myanmar and Laos, the challenge will be to use the knowledge and skills of large foreign companies operating in their territory to achieve the same level of professionalism among local suppliers and firms.

Table 3

World indicators of scientific publications, 2003 and 2016

\begin{tabular}{|c|c|c|c|c|c|}
\hline \multirow[t]{2}{*}{ Countries } & \multicolumn{2}{|c|}{ General number of publications } & \multirow[t]{2}{*}{ Changes, $\%$} & \multicolumn{2}{|c|}{$\begin{array}{l}\text { The share of the world } \\
\text { indicator (\%) }\end{array}$} \\
\hline & 2003 & 2016 & & 2003 & 2016 \\
\hline World & 1185942 & 2296271 & 1,9 & 100 & 100 \\
\hline European Union & 258646 & 410883 & 1,6 & 21,81 & 17,89 \\
\hline $\begin{array}{l}\text { East Asia and the } \\
\text { Pacific }\end{array}$ & 264447 & 728815 & 2,8 & 22,30 & 31,74 \\
\hline OECD & 940733 & 1379721 & 1,5 & 79,32 & 60,09 \\
\hline North America & 359530 & 466430 & 1,3 & 30,32 & 20,31 \\
\hline ASEAN: & 11170 & 53957 & 4,8 & 0,94 & 2,35 \\
\hline Singapore & 6037 & 11254 & 1,9 & $\mathbf{0 , 5 1}$ & 0,49 \\
\hline Malaysia & 1741 & 20332 & 11,7 & $\mathbf{0 , 1 5}$ & $\mathbf{0 , 8 9}$ \\
\hline Thailand & 2260 & 9582 & 4,2 & 0,19 & 0,42 \\
\hline Vietnam & 319 & 2961 & 9,3 & $\mathbf{0 , 0 3}$ & $\mathbf{0 , 1 3}$ \\
\hline Myanmar & 13 & 111 & 8,5 & 0,00 & $\mathbf{0 , 0 0}$ \\
\hline Philippines & 362 & 1569 & 4,3 & $\mathbf{0 , 0 3}$ & $\mathbf{0 , 0 7}$ \\
\hline Cambodia & 25 & 117 & 4,7 & 0,00 & 0,01 \\
\hline Indonesia & 360 & 7729 & 21,5 & $\mathbf{0 , 0 3}$ & 0,34 \\
\hline Laos & 18 & 85 & 4,7 & 0,00 & $\mathbf{0 , 0 0}$ \\
\hline Brunei & 35 & 217 & 6,2 & 0,00 & 0,01 \\
\hline
\end{tabular}


Table 4

The total number of patents, 2017

\begin{tabular}{|l|c|c|c|}
\hline \multicolumn{1}{|c|}{ Country } & Total applications & Applications of residents & Application of non-residents \\
\hline China & 1381594 & 1245709 & 135885 \\
\hline Japan & 318479 & 260290 & 58189 \\
\hline $\begin{array}{l}\text { South } \\
\text { Korea }\end{array}$ & 204775 & 159084 & 45691 \\
\hline Singapore & 10930 & 1609 & 9321 \\
\hline Indonesia & 9303 & 2271 & 7032 \\
\hline Malaysia & 7072 & 1166 & 5906 \\
\hline Vietnam & 5382 & 592 & 4790 \\
\hline Philippines & 3395 & 323 & 3072 \\
\hline Brunei & 107 & 8 & 99 \\
\hline Cambodia & 0 & 0 & 0 \\
\hline Myanmar & 0 & 0 & 0 \\
\hline Laos & 0 & 0 & 0 \\
\hline
\end{tabular}

No less important indicator of innovation activity than research expenses is royalty and license fees which are the main source of information about technology transfer and the level of internationalization of technological flows. Unlike the R\&D expenses, royalty and license fees are payments for ready-made technologies. In recent years, international flows of technology payments have increased that indicates an increase in the level of international knowledge transfer (Table 5). In a number of countries, the payment for the use of knowledge has grown much more than the global value. Estonia, Poland, Romania, India, Latvia, Lithuania, China became leaders in terms of increased fees for the use of intellectual property - more than thirty times growth of payments.

Table 5

Payments for use of intellectual property, billion USD

\begin{tabular}{|c|c|c|c|c|c|c|c|c|c|c|c|c|}
\hline \multirow{2}{*}{$\begin{array}{l}\text { Country / } \\
\text { Indicator }\end{array}$} & \multicolumn{2}{|c|}{2006} & \multicolumn{2}{|c|}{2008} & \multicolumn{2}{|c|}{2010} & \multicolumn{2}{|c|}{2012} & \multicolumn{2}{|c|}{2015} & \multicolumn{2}{|c|}{2017} \\
\hline & 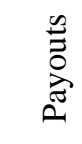 & 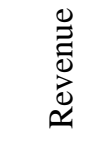 & 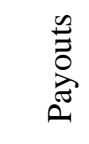 & $\begin{array}{l}\stackrel{0}{0} \\
\text { गे } \\
\approx\end{array}$ & 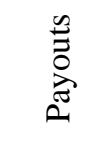 & $\begin{array}{l}\stackrel{0}{0} \\
\stackrel{0}{0} \\
\simeq\end{array}$ & 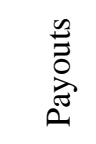 & $\begin{array}{l}\stackrel{0}{0} \\
\stackrel{0}{0} \\
\simeq\end{array}$ & 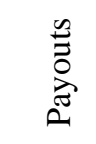 & $\begin{array}{l}\stackrel{0}{0} \\
\stackrel{\bar{\nu}}{0} \\
\simeq\end{array}$ & 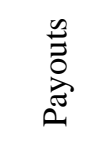 & 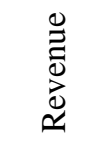 \\
\hline Japan & 15.5 & 20.09 & 18.3 & 25.71 & 18.77 & 26.68 & 19.89 & 31.89 & 17,04 & 36.47 & 21.34 & 41.74 \\
\hline Singapore & 9,59 & 0.53 & 13.48 & 0.78 & 16.91 & 0.97 & 22.66 & 1.86 & 21.87 & 8.8 & 19.83 & 8.23 \\
\hline China & 6,64 & 0.21 & 10.32 & 0.57 & 13,04 & 0.83 & 17.75 & 1.04 & 22.02 & 1.08 & 28.66 & 4.78 \\
\hline South Korea & 4.77 & 2.12 & 5.83 & 2.44 & 9.18 & 3.18 & 8,62 & 3.91 & 10.06 & 6.19 & 9.25 & 7.14 \\
\hline Malaysia & 0.95 & 0.26 & 1.27 & 1.99 & 1.32 & 1 & 1.54 & 1.36 & 1.29 & 0.88 & 1.83 & 2.86 \\
\hline Philippines & 0.35 & 0.63 & 0.38 & 0.26 & 0.45 & 0.42 & 0.47 & 0.76 & 0.62 & 1.12 & 0.75 & 1.69 \\
\hline Thailand & 2.05 & 0.46 & 2.57 & 1 & 2.08 & 0.35 & 3.61 & 1.05 & 4.12 & 0.85 & 4.28 & 1.02 \\
\hline Indonesia & 0.87 & 0.13 & 1.33 & 0.27 & 1.62 & 0.59 & 1.8 & 0.58 & 1.65 & 0.52 & 1.85 & 0.49 \\
\hline Cambodia & 0.69 & 0,013 & 0.64 & 0.053 & 0.63 & 0,034 & 1.1 & 0.38 & 1.3 & 0.05 & 1.3 & 0.09 \\
\hline Brunei & 0.55 & - & 0.73 & - & - & - & - & - & 1.36 & - & 1.73 & - \\
\hline Myanmar & - & & - & & - & & - & & 0.27 & 0.22 & 0.23 & 0.02 \\
\hline
\end{tabular}


Significant growth in payments for licenses and patents has also taken place in nearly all ASEAN member countries. Expenses on the use of intellectual property in absolute terms increased most in Japan - by 21.65 billion dollars, Singapore - by 7.7 billion dollars, South Korea -5.02 billion dollars and China -4.57 billion dollars. [3]

Correlation analysis allowed to detect that in countries such as China, South Korea, Vietnam, Cambodia and Laos, there is a close connection between GDP and the high-tech export. A regression analysis was conducted to establish dependence between these indicators, where the result feature - GDP, US dollars, factor - exports, US dollars; for China and South Korea also R\&D expenses, US dollars. On the basis of the calculations, we can conclude that the strongest dependence is observed in China and South Korea. When the volumes of exports change by $1 \%$, GDP changes by $0.86 \%$, and with growth or reduction of R\&D expenses by $1 \%$, China's GDP changes by $0.66 \%$, respectively.

The more significant impact of R\&D expenses on GDP can be seen in South Korea $1.86 \%$, and with changes in the volume of high-tech export, GDP changes by $0.58 \%$.

In countries such as Vietnam, Cambodia and Laos, the decrease or increase in hightech export by $1 \%$ entails changes in the country's GDP by $0.18 \%, 0.15 \%$ and $0.16 \%$ respectively. This is due to the fact that these countries do not invest a great amount of money on research, which affects the low share of high technology in the goods and services export. And as a result, it does not have such a strong impact on GDP as in neighboring countries.

In developed economies, the driving forces of foreign trade are the factors caused by innovation processes, leadership in the implementation of information and communication technologies. The influence of foreign trade on the economic growth of national economies is greatly enhanced, but the mechanism of this influence in groups of countries of the world economy is rather contradictory.

So, the analysis of international trade in high-tech products, payments for the use of knowledge, and R\&D expenses allows us to form an idea of the role of innovation activity of each ASEAN country in the integration process in this region.

Singapore has a special status and is the only country in ASEAN that shows high productivity, develops at the same level as the West countries and a country like Japan. Although the impact of its R \& D on the world level is not significant.

It is believed that Malaysia and Thailand are on a relatively high level next to Singapore. These two countries, like Singapore, have a level that is sufficient to develop relations with researchers from Japan, China and South Korea.

The experience of technologically advanced countries also suggests that a a wellconsidered mechanism of the state level with substantiation and prioritization, reliable monitoring of their implementation is a prerequisite for an effective innovation policy. The innovation policy of each state is oriented on the needs of the national innovation system. In any case, an international transfer of technologies is the key element and the final point of the direction of these actions [4].

The countries of Southeast Asia have successfully overcome the global financial crisis of 2008; many countries even have managed to avoid an economic downturn. Increasing economic growth in this region and stimulating both transboundary mobility of researchers and their narrower specialization is a priority task of member countries. Meanwhile, democratic reforms in Myanmar led to mitigating international sanctions, opening up prospects for growth, especially given that the government encourages export-oriented industries. The ASEAN Action Plan on Science, Technology and Innovation (2016-2020), in turn, focuses on social integration and sustainable development, including such sectors as Green Technology, Energy, Water Resources and Innovation for Life.

The countries of this region are increasingly cooperating with each other, as evidenced by trends in international scientific co-authorship. 
Directions for the development of innovation activities of ASEAN leading countries

Innovation policy is laid down in the annual plans for the development of the association. Again, all these sub-plans are usually an integral part of large-scale, long-term national programs such as medium-term national plans or national plans for economic and social development.

Consider in more detail the national innovation policies of the member countries of the integration association.

China. China's Plan for the Development of Science and Technology in the medium and long term provides the promotion of a program for the transformation of the Chinese economy into an innovative economy by 2020 . One of the tasks of this plan is to apply innovations in industry, agriculture and information and communication technologies to reduce pressures on energy, resources and the environment and to meet the needs of the aging population (innovations in pharmaceuticals, medical equipment). The share of $\mathrm{R} \& \mathrm{D}$ expenses in GDP is expected to rise to $2.5 \%$ by 2020 (1.34\% in 2005), and the contribution of scientific and technological progress to economic development by more than double, to above $60 \%$. Dependence on imported technologies will decrease to $30 \%$. [1]

Japan. Japan has set the following tasks: the departure from the priority of centralized inter-firm R \& D and the gradual reduction of resources allocated for these purposes; a sharp increase in the number of IP-partnership agreements with firms that are outside the traditional vertically integrated industrial associations and industrial groups; more than before, the use of research partnerships and strategic alliances with foreign, primarily US, companies; the growth of aggression through the absorption of high-tech firms in Japan and abroad; increase of interest in the venture capital market; strengthening cooperation on the basis of joint projects of private corporations with universities and state research institutes both in Japan and abroad. [6]

South Korea. The first innovation program was adopted in 1999 - "Vision 2025". The program described the scientific and technical development of the SK by 2015 . By 2025, it was planned to provide competitiveness in the field of research and development at the level of countries belonging to the "Big Seven". In this case, special attention was paid to the quality of technology, living standards, environmental pollution and the development of innovations in medicine. As part of the country's innovation development, the "creative economy" program was adopted at the state level. The peculiarity of the SK "creative economy" is that it also covers the traditional for SK industries like heavy, chemical industry and shipbuilding. The current economic policy of the state considers the innovative economy and creative enterprises as the next engine of the growth of the Korean economy. [7]

Indonesia. The Government of Indonesia seeks to enter into an era of innovative economies and to expand its competitiveness by attracting new technologies to support innovation as an engine of economic growth.

That is why it acknowledged that investment in applied research in key priority areas is crucial for an innovative economy. This is clearly reflected in Indonesia's main economic development plan for 2011-2025. The main directions of the master plan are the development of six economic corridors, the development of reliable links with ASEAN member countries and other countries of the world, and also the strengthening of human resources, science and innovation potential.

Malaysia. Innovation activities in Malaysia cover various areas of research, such as natural sciences, biotechnology, engineering and technology, information, computer and communication technologies, medicine and health, etc. The private sector in Malaysia plays an important role in $\mathrm{R} \& \mathrm{D}$, being the largest donor of gross expenses. About $84.9 \%$ of $\mathrm{R} \& \mathrm{D}$ expenses are funded by business. Innovation policy focuses on the development of high technology with inadequate funding for innovation in rural areas and social enterprises. 
Philippines. The country's political structures have developed the National Science and Technology Plan (NSTD) 2002-2020. It includes the science, technology and innovation sector, and also their role in improving productivity and well-being. There is a great potential for the development of effective links between science and production, however, this requires significant reforms in the university sector. There is a need to provide innovation support programs that will stimulate cooperation between industry and research. The recently implemented technology transfer law played a positive role in improving the commercialization of technologies.

Singapore. As in most countries, responsibility in the field of research and innovation in Singapore extends to various areas and departments. The ministries responsible for science and technology are the Ministries of: Trade and Industry; Education; Health Care; Defense; Environment and Water Resources; Information, Communication and Arts; National Development. The Singapore government has allocated $\$ 16.1$ billion to this sector. It has developed one of the largest tax and credit support innovative activities. Approximately $400 \%$ of investments can be deducted (but not more than $\$ 1.2$ million) from taxable income for improving innovation and productivity (development, research, equipment, training, approved design projects). This procedure is available to all businesses. Despite the strong interaction of the public sector in development and research, Singapore is one of the few countries in Southeast Asia, where business outlays for innovation activities are higher than public ones.

Thailand. Thailand's innovative policy is part of the political system of a constitutional monarchy with a strong role of the state and a limited number of legislative acts initiated by the parliament. All plans since 1986 were aimed at increasing the share of expenditures on innovation in the country's GDP, and, among other things, encouraged the promotion of innovation through the promotion of the use of new technologies, information networks, review of the legal system and the establishment of centers. The above plan aims to transform the balance of expenditures on science and technology from the state into the private sector. Currently, about $60 \%$ of funding comes from government sources. The plan focuses on creating a knowledge economy and a sustainable society.

Vietnam. The Government of Vietnam recognizes the important role of science and technology in the country's socio-economic development. In ten years of implementation of the Socio-Economic Development Strategy, the Vietnam economy has achieved relatively high and continuous growth rates, and improved living standards. The National Science and Technology Development Strategy until 2020 proposed a common goal of development in the synchronous mode of social sciences and humanities, natural sciences, technical and technological sciences; to make science and technology key motivating forces in meeting the basic needs of a modern industrial society. The state is the largest source of funding for research in Vietnam, which in turn is aimed at research institutes.

Thus, most ASEAN member states have formally recognized national innovation systems. Singapore became the first country in Southeast Asia, which managed to develop a coordinated innovation policy. Innovation in almost all ASEAN member states has become a key element for the successful economic development of the association as a whole.

Having analyzed the innovation system of the ASEAN Integration Association, it is possible to distinguish the strong positions of this association, namely:

- South-East Asia is a dynamically developing region of the world

- demonstrates a steady growth trend based on the benefits of intra-regional cooperation and deepening of economic links with neighboring countries;

- progressive open trading and investment regimes;

- significant experience of regional cooperation.

In addition, weak sides should be noted, such as:

- different levels of income, institutions and infrastructure among countries; 
- divergences in growth rates and in economic growth;

- slow implementation of commitments due to the need for consensus and the slow progress of domestic reforms;

- weak links between ASEAN and subregional programs;

- differences in productivity of innovation activity and innovation potential.

The main threats that may arise in the development of scientific and technological potential are:

- security problems in the region (territorial disputes);

- dependence of exports on turbulence in the global market;

- lack of effective regional cooperation on environmental issues, water, energy, food security, and disaster management (droughts, floods, earthquakes, volcanic eruptions).

It is impossible to create an ideal model for managing an innovation system at the regional level. A successful solution for different regions is the combination of a variety of policies that depend on the internal characteristics of the association, its capabilities, governance structure and activities of the regional authorities (table 6).

The main tasks of innovation policy and their solutions in ASEAN

Table 6

\begin{tabular}{|c|c|c|}
\hline \multirow{3}{*}{ 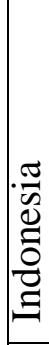 } & Infrastructure & $\begin{array}{l}\text { To accelerate development of transport infrastructure by } \\
\text { improving the regulatory framework }\end{array}$ \\
\hline & Human Capital Development & $\begin{array}{l}\text { Improving the outcomes of higher education and } \\
\text { reducing urban and rural inequalities in access to } \\
\text { educational infrastructure }\end{array}$ \\
\hline & Labor market & Reforming the labor market to increase employment \\
\hline \multirow[b]{3}{*}{$\frac{\substack{\frac{\pi}{\pi} \\
\frac{\pi}{\pi}}}{\sum}$} & Small and medium businesses & $\begin{array}{l}\text { Increasing small and medium enterprises with special } \\
\text { attention to capacity building and innovation }\end{array}$ \\
\hline & Human Capital Development & $\begin{array}{l}\text { Strengthening ties between industries and academic } \\
\text { institutions for training the workforce and the expansion } \\
\text { of research and development }\end{array}$ \\
\hline & Taxation and the tax system & $\begin{array}{l}\text { Reforming the tax regime and increasing the efficiency of } \\
\text { public expenditures to support the sustainability of public } \\
\text { finances }\end{array}$ \\
\hline \multirow{3}{*}{ 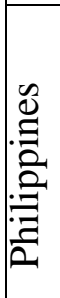 } & Infrastructure & $\begin{array}{l}\text { Increasing the financing of infrastructure development } \\
\text { and attracting more private sector participants }\end{array}$ \\
\hline & Human Capital Development & $\begin{array}{l}\text { Improving access to and quality of basic education and } \\
\text { strengthening of technical and vocational education }\end{array}$ \\
\hline & Taxation & $\begin{array}{l}\text { Reforming the tax system by improving tax collection } \\
\text { and expanding the tax base }\end{array}$ \\
\hline \multirow{3}{*}{ 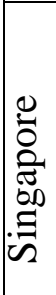 } & Human Capital Development & $\begin{array}{c}\text { Strengthening long-term learning through expansion } \\
\text { preschool education }\end{array}$ \\
\hline & Innovations & $\begin{array}{l}\text { Improving the effectiveness of innovation policy through } \\
\text { well-coordinated policy evaluation system }\end{array}$ \\
\hline & Small and medium businesses & $\begin{array}{l}\text { Increased development of SMEs by improving assistance } \\
\text { programs }\end{array}$ \\
\hline \multirow{3}{*}{ 胥 } & Health & $\begin{array}{c}\text { Reforming the health care system to ensure high quality } \\
\text { and free access to services }\end{array}$ \\
\hline & Human Capital Development & $\begin{array}{c}\text { Improving education by reducing disparities between } \\
\text { urban and rural areas }\end{array}$ \\
\hline & Agriculture & Increasing agricultural productivity and improving \\
\hline
\end{tabular}




\begin{tabular}{|c|c|c|}
\hline & & employment in the sector \\
\hline \multirow{3}{*}{ 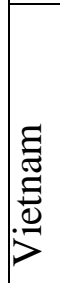 } & $\begin{array}{l}\text { Enterprise Development and } \\
\text { reforming public enterprises }\end{array}$ & $\begin{array}{l}\text { To speed up the reform of state enterprises, particularly } \\
\text { by improving the control and management }\end{array}$ \\
\hline & Macroeconomic management & Set the basis of monetary policy to curb inflation \\
\hline & Human Capital Development & $\begin{array}{c}\text { The increase in skilled labor by reforming higher } \\
\text { education }\end{array}$ \\
\hline
\end{tabular}

It should be noted that the main priority directions are mainly focused on the development of human capital, investment in infrastructure, and also regulatory and tax reforms. However, the main exceptions in this regard are Singapore and Malaysia, which have taken an important part in national innovation development strategies. Both countries have created special organizational structures for the development and coordination of innovation policy.

The attraction of FDI is a particularly important policy task for the countries of association and is seen as a means of modernizing local technological capabilities through various types of revenues to the local economy. Singapore is probably the most successful country in reaching this goal, identifying new market trends and developing policy incentives for attracting global players. Malaysia is also pursuing an aggressive strategy for attracting strategic FDI to stimulate its industrialization. Less developed countries of the association have recently followed a similar strategy of more developed group countries. For example, Cambodia adopted a number of rules and introduced tax incentives to attract FDI.

Conclusions. Among the participating countries, the development of innovation policies is noted in countries such as China, Japan, South Korea and Singapore. These countries have created special organizational structures for the development and coordination of innovation policy. In spite of this, other countries also follow the development of successful innovation strategies for accelerating innovation in the countries and integration as a whole.

Singapore has a special status and is the only country in ASEAN, which shows high productivity, develops at the level with the West countries and a country like Japan. Although the impact of its R\&D on the world level is not significant. Malaysia and Thailand are on a relatively high level next to Singapore. The relatively high share of R\&D is provided by the domestic sector in three countries: Singapore, Philippines and Malaysia. In the latter case, this is most likely the result of the presence of multinational companies in them.

ASEAN countries are increasingly cooperating with each other, as evidenced by trends in international scientific co-authorship. For many countries, the challenge will be to strengthen and diversify the participation of the business sector in a wide range of industrial sectors, especially given that the cycle of lowering prices for commodities has begun that adds even more importance to the development of an innovative growth policy.

In order to accelerate the investment and innovation process in the ASEAN countries, it is necessary to develop science-intensive sectoral programs aimed at developing technologies in selected priority sectors (aircraft building, shipbuilding, space, nuclear complex, new transport technologies, telecommunications, remote access solutions, trade, information security, universalization of services).

\section{Список використаної літератури}

1. Дун Яньхуэй Просыпающийся вулкан. Перспективы инновационной политики Китая / Дун Яньхуэй // Креативная экономика. - 2009. - Том 3. - № 6. - C. 40-44 ; Dun Yankhuey Prosypayushchiysya vulkan. Perspektivy innovatsionnoy politiki Kitaya / Dun 
Yankhuey // Kreativnaya ekonomika. - 2009. - Tom 3. - № 6. - S. 40-44

2. Global Innovation Index 2017 [Electronic resource]. - Mode of access : https://www.globalinnovationindex.org/

3. The World Bank [Electronic resource]. - Mode of access : http://econ.worldbank.org/

4. Ministry of Science, Technology and Environment (MOSTE) [Electronic resource].

- Mode of access : http://www.mosti.gov.my/en/corporate-profile/about-mosti/

5. Knoema [Electronic resource]. - Mode of access : https://knoema.ru

6. RangEconomic [Electronic resource]. - Mode of access : www.rangeconomic.ru

7. Korean Media Review October 2013 [Electronic resource]. - Mode of access : http://www.ved.gov.ru/exportcountries/kr/kr_ru_relations/kr_news/12050.html

Стаття надійшла до редакції 14.04.2019.

\section{О.А. Беззубченко \\ Т. Склярова}

\section{СУЧАСНІ ТЕНДЕНЦЇ̈ РОЗВИТКУ ІННОВАЦІЙНОЇ ДІЯЛЬНОСТІ КРАЇН АЗІЙСЬКО-ТИХООКЕАНСЬКОГО РЕГІОНУ}

У дослідженні здійснено аналіз інноваційної діяльності Азіатсько-Тихоокеанського регіону, в основному лідерів інтеграчійного об'єднання АСЕАН. Визначено напрями розвитку інноваційної політики країн АСЕАН в контексті трансформацї світової економіки; досліджено обсяги експорту високотехнологічних товарів країн АСЕАН та витрат на НДДКР; визначено вплив інновачійної діяльності на економічний розвиток країн, а точніше - високотехнологічного експорту та витрат НДДКР; запропоновано напрями вирішення існуючих проблем в сфері інновачійної діяльності.

Ключові слова: АСЕАН, інноваційна діяльність, високотехнологічні галузі, НДДКР

УДК 323.174:314.7(477)(045)

\section{Х. С. Мітюшкіна \\ І. Я. Бернацька}

\section{ЗАРУБІЖНИЙ ДОСВІД РЕФОРМУВАННЯ ЕКОНОМІКИ ПРОМИСЛОВИХ МІСТ}

Статтю присвячено проблемам реформування монопрофільної структури економіки промислових міст. Досліджено сутність та особливості монопрофільної структури економіки, визначено иляхи реструктуризації відповідних економік. Вивчено світові практики та інструментарій вирімення проблем монопрофільності міст. Проаналізовано міжнародний досвід (США, Японії, Німеччини, Великобританії $i$ Канади). показано, щуо прогрес у вирішенні проблем промислових міст залежить від стратегічних партнерських відносин між державними, регіональними та локальними органами управління, а також від їх співпращі з бізнесом. Зарубіжний досвід показує, щзо грамотно розроблена $i$ реалізована програма диверсифікації економіки монопрофільних міст дає відчутні результати, перш за все, в підвищенні якості життя населення, розвитку їх доходів, формуванні нових сфер зайнятості.

Доведено необхідність впровадження кращого закордонного досвіду для вирішення проблем диверсифікації економіки міст Украӥни. Визначено напрямки розвитку диверсифікачії економіки на основі взаємодії з містоутворюючими 